\title{
Az élő hagyománytól a kulturális örökségig: az örmény városépítészet Erdélyben Tamáska Máté: Örmény városépitészet Erdélyben
}

\author{
Blénesi Éva² \\ https://doi.org/10.5१६24/SzocSzemle.2021.1.6
}

Ha pozitív túlélési stratégiákra keresünk példákat a rendkívüli kihívásoknak kitett népek történetében, akkor az örmények kétségkívül kiemelkednek ebben a vonatkozásban, s ez alól az erdélyi örmények sem képeznek kivételt. Amikor 1719-ben a szászok egy pestisjárvány ürügyén kiüzték a nemkívánatos konkurenciának számító örményeket Besztercéről, e sorscsapásra ők azzal válaszoltak, hogy a kiưzést követően Szamosújváron telepedtek meg, ahol a semmiből, gyakorlatilag egy libalegelő helyén, létrehozták az erdélyi „örmény metropoliszt”, amely az egyetlen tervszerűen megépített városnak számított Erdélyben.

Erdély e sajátos identitású kisebbségéről, az örményekről kialakult közismert kép alapjaként a kereskedést és a városépítést említi a szakirodalom, amely sokáig a századforduló romantikus és mítoszteremtő történetírói anyagait használta alapul, elsősorban Szongott Kristóf ${ }^{3}$ forrásaira hagyatkozva. Ennek újraértékelésére csak az elmúlt évtizedekben került sor. E folyamatnak a fontos állomása Tamáska Máté: Örmény városépítészet Erdélyben című könyve, amely elsőként hasonlítja össze a négy nagy erdélyi örmény kolóniának otthont adó, Szamosújvár, Erzsébetváros, Gyergyószentmiklós és Csíkszépvíz városépítészi fejlődését a 18. század elejétől a századfordulóig.

A szerző több tézist is megfogalmaz könyvének bevezetőjében. Szerinte az örmény városépítészetről beszélve több megközelítés is elképzelhető: egyrészt regionális, azaz Erdély sajátos viszonyaiból kiindulva, másrészt az örménység építészeti diskurzusának a kontextusában. Ez utóbbi megközelítést azért nem találja célravezetőnek, mert a római katolikus egyházzal unióra lépő erdélyi örménység a 19. század elejére gyakorlatilag elveszítette kulturális kapcsolatait az őshazájával, ami egyfelől nyelvvesztéssel járt, másfelől azzal, hogy a közép-európai katolikus művelődés

\footnotetext{
Tamáska Máté (2020): Örmény városépítészet Erdélyben. Budapest, L’Harmattan - Pázmány Péter Katolikus Egyetem.

2 Email: eva.blenesi59@gmail.com

3 Szongott Kristóf (1893): Szamosújvár, a magyar-örmény metropolisz írásban és képekben, Auróra, Szamosújvár.; Szongott Kristóf (1901-1903): A magyar örmény metropolisz, 1-3. kötet, Auróra, Szamosújvár.
} 
hatáskörébe került. Ez a folyamat az építészetben korábban lezajlott, így a 18-19. századi erdélyi örmény építészet nem mutat rokonságot Örményország hagyományaival. Az a bizánci építészetből kifejlődő keleties formanyelv, amely a szomszédos Moldováig elkísérte az örménységet, a Kárpátokat átlépve megszakadt. Ebből a tényből kiindulva állítja fel Tamáska a könyve bevezetőjének első tézisét, miszerint ha a szakrális örmény építészetben sincs áthatás a Kaukázus, a Krím, Moldova, illetve Erdély között, akkor még kevésbé várható ez el a világi emlékek, kiváltképp a városépítészet terén. Ezt az alaptézist elfogadva bontja ki a szerző a témáját elsősorban Erdély viszonyaiból kiindulva.

A másik alapvető tézis, hogy a szerző a városépítészetet építészetszociológiai módszerekkel elemezhető kulturális produktumnak tekinti, tehát a klasszikus építészeti vizsgálattal ellentétben nem a formát magát tekinti a vizsgálódás tárgyának, hanem annak a tartalomnak a megértését túzi ki célul, amelyet a forma kifejez és hordoz, vagyis annak megértését, hogy milyen kulturális tartalmakat közvetít az adott építészeti mintázat. E felfogás szerint tehát az örmény építészetet egy kulturális-társadalmi folyamatként kell felfogni, nem pedig építőművészeti alkotásként. Jelen esetben pedig a kulturális folyamaton az örmény kolónia beilleszkedésének, majd asszimilációjának a történetét, illetve ennek a történetnek a térbeliségét, az építészeti lenyomatát kell érteni.

A szerző olyan kérdésekre keresi a választ, mint hogy kiket tekintett az örmény kolónia mintaadó csoportnak, miként változott az ízlése, hogyan viszonyult a helybéli építészeti tradíciókhoz. Ezen kérdésfelvetések okán a „kulturális beilleszkedés”, az „asszimiláció”, a „mintakövetés” az egész könyvön végigvonuló kulcsszavakká válnak.

Szerkezeti felépítését tekintve a kötet négy nagy tematikus egységet tartalmaz, ahol a szerző elsőként a tudománytörténeti, módszertani kérdéseket tisztázza, majd a kulturális önazonosság időben változó mintázatait tárgyalja. Az örménység identitásával foglalkozó rész gazdag szakirodalmi apparátusra épít, miközben egy négylépcsős asszimilációs folyamatot vázol fel, elsősorban Szamosújvár példájára hivatkozva. Az örménység identitásának tárgyalásakor a szerző rámutat arra, hogy a befogadó társadalom iránti lojalitás és a korlátozott egyházi autonómia mellett a 19. századi örménykép harmadik alappillére a civilizációs teljesítmény hangsúlyozása. A civilizációs teljesítmény kérdését azért emeli ki Tamáska, mert szerinte ebbe a toposzba két szempontból is illeszkedik a városépítés témája: egyfelől az ősi örmény főváros, Ani kollektív emlékezetből való beemelése, másfelől Szamosújvár kiemelkedő szerepe miatt. Jóllehet a helytörténeti munkák Gyergyószentmiklós, Erzsébetváros és Csíkszépvíz esetében is hangsúlyozzák a betelepülő örmény diaszpóra városépítészeti teljesítményét, de mindemellett a regionális beágyazottságot is. Azonban egyedül Szamosújvár tekintetében szokás „tisztán” örmény építészetet emlegetni, ahol az örmény jelleg és az építészeti nívó együtt teremtett alapot a város különleges státuszának kialakulásához. Tamáska úgy fogalmaz, hogy „Szamosújvár 
a szent és a mitizált Ani erdélyi megfelelője, a magyar-örmény identitás emlékezetének a helye." (Tamáska 2020: 42)

A második tematikai egység továbbra is az örmény kolóniák külső kapcsolatait vizsgálja, itt azonban már a várostörténeti szempontok kerülnek előtérbe. Kiemeli a szerző, hogy a 18. század elején az örmény kereskedőközpontok „új városok” voltak egy már évszázadok óta működő, stabil településrendszerben, következésképpen az önálló örmény városfejlődésnek meg kellett küzdenie azzal a hátránnyal, hogy az örmények földrajzi értelemben nem a legelőnyösebb helyzeti pozíciókat foglalhatták el. Az eleve perifériás helyzetű Székelyföld ugyanakkor térben és társadalmi tudatban is elkülönülő entitást képezett Erdélyen belül, míg Szamosújvárnak és Erzsébetvárosnak már olyan meglévő centrumokkal kellett felvennie a versenyt, mint Kolozsvár, Beszterce, Nagyszeben és Medgyes.

A harmadik tematikus egységben a szerző a városok szerkezetét, az utca- és telekrendszereket, mindezek kulturális beágyazottságát tárgyalja. Tulajdonképpen itt válik világossá, hogy milyen döntő szerepe volt az örménység státuszának a településkép alakulása szempontjából. Ugyanakkor a szerző arra is rámutat, hogy az örmény város nem teljesen szabad területen épült fel, hanem egy már meglévő városhoz, vagy váraljai településmaghoz lazán vagy szorosabban csatlakozva. Tehát az örmény városok szerkezetében mindig kimutatható egyfajta alkalmazkodási kényszer. A szerző az összehasonlítás negyedik szintjén a 20. század eleji városképekről ad leírást építve a bőséges forrásanyagra: képeslapokra, kataszteri térképekre, a modern népszámlálás 1910-es épületstatisztikai adatsoraira, a megélénkülő honismereti irodalomra.

A város és vidéke változó kapcsolatai címú 5. fejezetben a szerző több összefüggést is megfogalmaz a nagytáji környezet kapcsán. Elsőként említi, hogy a városok és a táj szoros kapcsolata magyarázatot kínál a megtelepülő örmények gyors építészeti alkalmazkodására, de arra is, hogy miként alakulhatott ki viszonylag nagy különbség a kolóniák építészete között. A második sajátosság, hogy a tájtól és az elsődleges tájműveléstől való távolság miként erősítette a kolóniák építésze közötti hasonlóságot, hiszen az örmények kezdetben mind a négy helyszínen hasonló státusszal bírtak, lévén kereskedők és kisiparosok, és ennek megfelelően tükröződik az építészetükben a mezőgazdasági őstermeléstől független telekhasználat vagy a raktározási igény a pincétől a padlásig. A harmadik szempont, hogy a 17. századig Erdélyben új település csak a már meglévő rendi keretekhez alkalmazkodva jöhetett létre. Tamáska arra is rámutat, hogy a városépítészet nem determinisztikus, hiszen a természeti környezet többféle építőanyagot kínál, és az, hogy milyen építőanyagot használ a népesség, a szokásaitól és a tudásától is függ. Erdélyben az örmények két kulturális régióban telepedtek le: Szászföldön és Székelyföldön. Mindkettő védelmi célból létrejött középkori eredetű autonómiaterület volt. A szászföldi részeken főleg kőből, míg a székelyföldi területeken elsősorban fából építkeztek, és az itt megtelepedett örmény kolóniák alkalmazkodtak a helyi tradíciókhoz. 
Tamáska abban látja az örmény kolóniák látványos fejlődésének egyik kulcsmozzanatát, hogy az erdélyi városhálózat egyenetlenséget és hézagosságot mutatott. A 18. századi abszolút monarchia az elfoglalt uradalmi területeken állandó adminisztratív funkciókat ellátó egységeket tartott fenn, és a régiókon átívelő gazdasági mechanizmusokat múködtetett, ám ehhez a középkorból örökölt városhálózat sem Észak-Erdélyben, sem pedig Székelyföldön nem volt megfelelő. Itt részben a bécsi udvar támogatásával a 18-19. századi városhálózati átalakulás részeként létrejött egy közép- és kisvárosi városláncolat. Tamáska szerint ebbe a folyamatba ágyazottan válik érthetővé Szamosújvár és Gyergyószentmiklós eltérő időpontú látványos fejlődése, Erzsébetváros ambivalens városiasodása és Csíkszépvíz helyzete, ami kevésbé tudott a városiasodás áramába bekapcsolódni. Az örmény kolóniák városainak általános tendenciáin kívül a szerző rámutat egy fontos sajátosságra is, jelesül arra, hogy miközben a 18. században a városiasodás kereskedelmi funkciói voltak bennük túlsúlyban, addig a 19. század végére az állami-közigazgatási funkciók kerültek előtérbe. Jóllehet ezek a folyamatok más városokra is jellemzőek voltak, az átalakulás dinamikája, amellyel a kereskedőváros adminisztratív várossá vált, már jellegzetesen örmény vonásnak tekinthető.

Tamáska arra is kitér, hogy az örmények alkalmazkodása a települési struktúrákhoz a települések belső szerkezetében is kimutatható, hiszen a már meglévő valóságos uradalmi falakon, illetve a szimbolikus társadalmi falakon kívül kellett felépíteniük a kolóniáikat. E folyamat jellemzőjeként a 18. és 19. század során az örmény kolóniák válnak az új települési centrumokká vagy úgy, mint Szamosújváron és Csíkszépvízen, ahol a korábbi falumaghoz képest a település egészének centruma eltolódott, vagy pedig úgy, mint Erzsébetváros és Gyergyószentmiklós esetében, ahol a legértékesebb belső telkek fokozatosan az örmények birtokába kerültek.

Tamáska szerteágazó és sokirányú megközelítésmódjának egyik jellegzetessége, hogy az összehasonlító városszerkezetek bemutatásában a makroszintű megközelítések mellett helyet kapnak a mikroszintű elemzések is, így nemcsak átfogó képet kapunk a városokról, hanem az egyes városok sajátos karakterét adó épületeket is bemutatja. Külön alfejezetet szentel a szakrális építészetnek, majd a középületeknek, végül felvázolja azt a folyamatot, amelyben tetten érhető a változás az örmény háztól a bérpalotákig.

Tamáska könyvének egyik izgalmas fejezete az örmény településkép vizuális öszszefüggéseinek értelmezése, amelyben az analitikus elemzések helyett a városépítészeti együttesek kapcsolatai kerülnek előtérbe. Azt a hatást próbálja tetten érni a szerző, amelyet a városkép a szemlélőre gyakorol. Ugyanakkor számol azzal a jelenséggel is, hogy a 20. század eleji városképek értelmezésekor a korabeli élmények már csak korlátozottan rekonstruálhatóak, miközben a térszerkezetek általános összefüggései fennmaradtak. Ilyen maradandó hangsúlyokat képeznek a templomok, míg a lakosság összetételének megváltozásával a századfordulón olyan jelentős örmény épületelemek, mint a korzó, a kávéházak, a korcsolyapályák, a kaszinók már nem 
részei a városképnek. A szerző a városképek leírásakor azonban nem hagyatkozik pusztán a ma megfigyelhető állapotokra, hanem bőven merít a korabeli képeslapgyűjteményből is. Az Örmény városképek című 8. fejezetben külön alfejezetet szentel a város sziluettjének (A sziluett), vagyis annak a látképnek a bemutatására, amely szerinte a település táji beágyazottságának a legfontosabb összetevője. Tamáska kiemeli, hogy a táj és város egyedül Szamosújváron olvadt egy sziluetté, összességében pedig azt a következtetést vonja le, hogy miközben Csíkszépvízen az örmény házak hangsúlyozottan vidékies környezetben jelennek meg, addig a hasonló fekvésű Gyergyószentmiklóson a városias jelleg válik hangsúlyossá; s míg a kevésbé városias jellegű Erzsébetvárosban az urbánus karakter kerül előtérbe, Szamosújvár a város és környezete harmóniáját rögzítő sziluettként maradt fenn a köztudatban.

Az utcák és a terek vonatkozásában a szerző arra hívja fel a figyelmet, hogy az örmény városok utcaképét elsősorban két egymásnak látszólag ellentmondó vonás határozza meg, ahol az örmény utcakép egyfelől a helyi hagyományokat és alapanyagokat felhasználó építészet lenyomata, másfelől magába olvasztott városias és nagyvárosias mintákat. Példaként emlegeti Szamosújvárt, ahol környékbeli vidéki kúriaépítészet ötvöződött a kolozsvári, ausztriai és dél-csehországi mesterek díszítőművészetével. Fontos elemként értékeli a szerző az örmény polgárság értékrendjéhez hozzá tartozó közterületek parkosítását.

A lakóházak építészeti jellegzetességeit illetően Tamáska kiemeli, hogy a 18. századi örmény családok dinasztiát alkottak, és a városi ház mint kicsinyített kastély vagy kúria a család státuszszimbólumává vált. Ugyanakkor a lakóházaknak kereskedelmi igényeknek is meg kellett felelniük, így a városmagok reprezentatív barokk jellege keveredett a gazdasági tevékenységek színtereivel, ahol az örmények a környezetből átvett építészeti mintákkal igyekeztek csökkenteni a különbségeket a befogadó népesség, valamint saját értékrendjük és életmódjuk között. A 19. század vége viszont jelentős változást hozott, amikor a korábbi örmény barokk városkép fokozatosan átadta helyét az új városi léptékeknek. Ez a folyamat elválaszthatatlan volt az örménység új szerepétől, akik az idegenből rendi kiváltságossá, majd a magyar a nemzet elkötelezett híveivé váltak. A századforduló impozáns hivatali épületei és iskolái az örményeknek ezt a magyar államnemzethez fűződő viszonyát jelenítették meg a városképben. Az örmény városképeknek továbbra is kulcsfontosságú eleme maradt a szakrális építkezés, amelyben komoly szerepet játszott az újonnan a római egyházhoz kapcsolódott népesség lojalitásának hangsúlyozása. Tamáska szerint „[a] városképekben egyszerre megjelenő szegregáció és integráció híven fejezi ki a 20. század elejének belső társadalmi mozgásait. A többségből egyre inkább kisebbséggé (Erzsébetváros, Szamosújvár), illetve a jelentős kisebbségből diaszpórává (Gyergyószentmiklós, Csíkszépvíz) zsugorodó örmények számára a beolvadás elkerülhetetlenné vált.” Az, hogy az erdélyi örménység jelentős része elhagyta a kolóniákat, és részben átköltözött Romániából Magyarországra, az örmény városszerkezetek alakulásában is hűen tükröződött. Ezért is fogalmazott úgy a szerző a könyve be- 
vezetőjében, hogy „Az erdélyi örmény építészet a 20. században élő hagyományból kulturális örökséggé vált”. (Tamáska 2020: 13). Könyvének zárórészében kiemeli a szerző, hogy „[a]z erdélyi örmény városépítészet összehasonlító vizsgálatának alapvető célja nem az építészeti formának a leírása volt, hanem a formában kifejeződő társadalmi tartalomnak a feltárása" (Tamáska 2020: 177).

Tamáska Máté Örmény városépitészet Erdélyben című könyve korszerü, multidiszciplináris megközelítésben mutatja be az erdélyi örménység városépítészeti sajátosságait. Nyelvezetét nem terheli fölösleges szakzsargon, plasztikus leírásai pedig nem csak a szúk szakma számára teszik élvezhetővé a szövegét. Jelen könyv egy újfajta szemléletmód bemutatása jelentős stációjának is tekinthető, de a szerzőnek azon törekvéseként is figyelemre méltó, hogy az építészettel foglalkozó szakmához és az átlagolvasóhoz egyaránt közelebb hozza a településkép humán irányultságú vizsgálatát és a társadalomtörténeti megalapozottságú építészetszociológia meghonosítását. 